\title{
Large Cleaved Cell
}

National Cancer Institute

\section{Source}

National Cancer Institute. Large Cleaved Cell. NCI Thesaurus. Code C32923.

An activated lymphocyte with a diameter of about 12 micrometers, a nucleus with deep folds or clefts and clumped chromatin. 